\title{
TRP Channels: Their Function and Potentiality as Drug Targets
}

\author{
Motohiro Nishida, Koichiro Kuwahara, Daisuke Kozai, \\ Reiko Sakaguchi, and Yasuo Mori
}

\begin{abstract}
The transient receptor potential (TRP) proteins are a family of ion channels that act as cellular sensors as well as signal integrators. Several members of the TRP family are sensitive to changes in cellular redox status. Among them, TRPA1 is remarkably susceptible to various oxidants and is known to mediate neuropathic pain and respiratory, vascular, and gastrointestinal functions, making TRPA1 an attractive therapeutic target. However, a method to achieve selective modulation of TRPA1 by small molecules has not yet been established. Most recently, we found that a novel $N$-nitrosamine compound activates TRPA1 by $S$-nitrosylation (the addition of a nitric oxide (NO) group to cysteine thiol) and does
\end{abstract}

\footnotetext{
M. Nishida

Division of Cardiocirculatory Signaling, Okazaki Institute for Integrative Bioscience, National Institute for Physiological Sciences, National Institutes of Natural Sciences, Myodaiji-cho, Okazaki, Aichi 444-8787, Japan

K. Kuwahara

Department of Cardiovascular Medicine, Graduate School of Medicine, Kyoto University, Sakyo-ku, Kyoto 606-8507, Japan

D. Kozai

Department of Synthetic Chemistry and Biological Chemistry, Graduate School of Engineering, Kyoto University, Katsura Campus, Nishikyo-ku, Kyoto 615-8510, Japan

R. Sakaguchi

Department of Synthetic Chemistry and Biological Chemistry, Graduate School of Engineering, Kyoto University, Katsura Campus, Nishikyo-ku, Kyoto 615-8510, Japan

World Premier International Research Initiative-Institute for Integrated Cell-Material Sciences, Kyoto University, Katsura Campus, Nishikyo-ku, Kyoto 615-8510, Japan

Y. Mori, Ph.D. ( $\square)$

Department of Technology and Ecology, Hall of Global Environmental Studies, Kyoto University, Katsura Campus, Nishikyo-ku, Kyoto 615-8510, Japan

World Premier International Research Initiative-Institute for Integrated Cell-Material Sciences, Kyoto University, Katsura Campus, Nishikyo-ku, Kyoto 615-8510, Japan e-mail: mori@sbchem.kyoto-u.ac.jp
} 
so with significant selectivity over other NO-sensitive TRP channels. It is proposed that this subtype selectivity is conferred through synergistic effects of electrophilic cysteine transnitrosylation and molecular recognition of the non-electrophilic moiety on the $N$-nitrosamine. On the other hand, TRPCs are typical receptor-activated $\mathrm{Ca}^{2+}$-permeable cation channels, which sense messenger molecules generated downstream of phospholipase activation. Previously, activation of TRPC3 and TRPC6 by diacylglycerol has been reported to play important roles in the pathogenesis of cardiac hypertrophy. Also, a pyrazole compound, Pyr3, which selectively inhibits TRPC3, suppresses cardiac hypertrophy in animal models in vitro and in vivo. We have most recently found that Pyr3 and related compounds are effective in suppressing cardiac fibrosis and ischemia responsible for cardiac remodeling as well. Thus, in this chapter, we describe the molecular pharmacology of TRP modulators and discuss their modulatory mechanisms and pharmacological actions.

Keywords Electrophile $\cdot$ Nitric oxide $\cdot$ Non-electrophilic compound $\bullet$ Oxidative stress $\bullet$ Transnitrosylation $\bullet$ TRP channel $\bullet$ TRPA1

\section{Introduction}

In 1989, the transient receptor potential (TRP) protein was first identified as being encoded by the trp gene of Drosophila [1]. The TRP protein superfamily consists of a diverse group of calcium ion $\left(\mathrm{Ca}^{2+}\right)$-permeable non-selective cation channels, and is found in most living organisms [2-4]. Mammalian TRP channels are currently divided into TRPC (canonical), TRPV (vanilloid), TRPM (melastatin), TRPP (polycystic kidney disease), TRPML (mucolipin) and TRPA (ankyrin) subfamilies. TRP channels have a tetrameric subunit stoichiometry, and each subunit contains cytoplasmic N- and C-terminal regions, six transmembrane (TM) domains and a pore-forming region between TM5 and TM6. TRP channels are sensitive to a variety of stimuli, including receptor stimulation, temperature, plant-derived compounds, environmental irritants, osmotic pressure, mechanical stress, $\mathrm{pH}$, and voltage from the extracellular and intracellular milieu, and are involved in diverse physiological and pathological processes [2, 5-16].

Certain TRP channels respond well to mediators of oxidative stress, such as reactive oxygen species (ROS), reactive nitrogen species (RNS), and other electrophiles [17-20]. Canonically known as damaging molecules causing cellular dysfunction, ROS and RNS are increasingly recognized as cell-signaling molecules [21, 22]. The first identified ROS-sensitive TRP channel, TRPM2, is activated by hydrogen peroxide $\left(\mathrm{H}_{2} \mathrm{O}_{2}\right)$ and mediates several cellular responses, including cell death and chemokine production [23-26]. TRPM7, which can be modulated by both ROS and RNS, is an essential mediator of anoxic cell death [27, 28]. Some members of the TRPC and TRPV subfamily, including TRPC5 and TRPV1, are activated by $\mathrm{H}_{2} \mathrm{O}_{2}$, nitric oxide (NO), and reactive disulfides [29]. In addition, TRPA1 is remarkably 
activated by various oxidants, including ROS, RNS, reactive disulfides, and other electrophiles [30-33].

Among TRP subfamilies, TRPCs are typical receptor-activated $\mathrm{Ca}^{2+}$-permeable cation channels, which sense messenger molecules generated downstream of phospholipase activation. Previously, Kuwahara [34] and Nishida [35] separately showed that TRPC3 and TRPC6 activated by DAG play important roles in the pathogenesis of cardiac hypertrophy. Also, Mori developed a pyrazole compound, Pyr3, which selectively inhibits TRPC3 and suppresses cardiac hypertrophy in animal models in vitro and in vivo [36]. In our recent progress in studying the pharmacological action of Pyr3 and related compounds, their modulators have turned out to be highly effective in suppressing cardiac fibrosis and ischemia responsible for cardiac remodeling. Thus, TRPC3 and TRPC6 are emerging as critical targets in development of drugs relevant to therapies for heart failure.

\section{Modulation of Trpa1 Channel Activity}

\section{Oxidation Sensitivity of the Trpal Channel}

TRPA1 responds to various oxidative stress mediators and environmental electrophiles (Table 1). Cysteine residues within a protein are direct targets for the oxidant signal reaction $[74,75]$. TRPA1 is not an exception in this characteristics. Its activation by oxidants is proposed to be mediated via oxidative modification of the free sulfhydryl group of cysteine residues, as described for the activation of TRPC5 and TRPV1 [29, 76].

For TRPA1, the oxidation sites have been identified (Fig. 1). Simultaneous mutation of three cysteine residues within the cytoplasmic N-terminus of human TRPA1 (Cys621, Cys641, and Cys665) decreases TRPA1 channel activation by several exogenous cysteine-modifying electrophiles, such as isothiocyanates (e.g. AITC), $\alpha, \beta$-unsaturated aldehyde compounds (e.g. acrolein, $N$-methylmaleimide, and cinnamaldehyde), allicin from garlic, and diallyl disulfide [30, 37, 38]. Lys710 is also suggested to be involved in the activation of TRPA1 by AITC. Three cysteine residues in mouse TRPA1 (Cys415, Cys422, and Cys622, conserved in the human homolog as Cys414, Cys421, and Cys621) were independently identified as the target sites for AITC and cinnamaldehyde [31]. Intracellular $\mathrm{Zn}^{2+}$ also activates human TRPA1 by interacting with Cys641 and C-terminal Cys1021/His983 [78]. Systematic evaluation of TRP channels was performed using a series of reactive disulfides, such as bis(5-nitro-2-pyridyl) disulfide and diallyl disulfide [33]. These compounds possess a different electron acceptor (oxidation) capacity (manifested as redox potential), and these studies revealed that only TRPA1 responds to the inert electrophile diallyl disulfide among TRP channels. Thus, TRPA1 can sense inert oxidant $\mathrm{O}_{2}$, and $\mathrm{O}_{2}$ activation of TRPA1 is by oxidation of Cys633 and/or Cys856, located intracellularly within, respectively, the $\mathrm{N}$-terminal region and the putative linker region between TM4 and TM5 [33]. In addition, TRPA1 cysteine residues 
Table 1 TRPA1 modulators

\begin{tabular}{|c|c|c|}
\hline Class of compound & Compound & Reference \\
\hline \multirow[t]{23}{*}{ Activators (electrophilic) } & Allyl isothiocyanate (AITC) & {$[30]$} \\
\hline & Acrolein & {$[30]$} \\
\hline & $\mathrm{N}$-methylmaleimide & {$[30]$} \\
\hline & Cinnamaldehyde & {$[30]$} \\
\hline & Bis(5-nitro-2-pyridyl) disulfide & [33] \\
\hline & Allicin & {$[37,38]$} \\
\hline & Diallyl disulfide & {$[30]$} \\
\hline & 2-Chloroacetophenone & {$[17,39]$} \\
\hline & Methylvinylketone & [40] \\
\hline & Umbellulone & [41] \\
\hline & Ligustilide & {$[42]$} \\
\hline & Hydroxy- $\alpha$-sanshool $(\alpha-\mathrm{SOH})$ & [43] \\
\hline & 6-Shogaol & [43] \\
\hline & Etodolac & {$[44]$} \\
\hline & Glibenclamide & {$[45]$} \\
\hline & Auranofin & {$[46]$} \\
\hline & 4-Hydroxy-2-nonenal & {$[47]$} \\
\hline & 4-Hydroxyhexenal & [48] \\
\hline & 4-Oxo-2-nonenal & {$[48]$} \\
\hline & Nitrooleic acid & [49] \\
\hline & $15 \mathrm{~d}-\mathrm{PGJ} \mathrm{J}_{2}$ & {$[48]$} \\
\hline & Methylglyoxal & {$[50,51]$} \\
\hline & Oleocanthal & {$[52]$} \\
\hline \multirow[t]{15}{*}{ Activators (non-electrophilic) } & Icilin & {$[30]$} \\
\hline & 2-Aminoethyl diphenylborinate & [31] \\
\hline & Carvacrol & {$[53]$} \\
\hline & Flufenamic acid & {$[54]$} \\
\hline & Isoflurane & {$[55]$} \\
\hline & Farnesyl thiosalicylic acid & {$[56]$} \\
\hline & NPPB & {$[57]$} \\
\hline & Thymol & {$[53]$} \\
\hline & 2,6-Diisopropylphenol (propofol) & {$[53]$} \\
\hline & Docosahexaenoic acid (DHA) & {$[58]$} \\
\hline & Arachidonic acid & [59] \\
\hline & 6-Paradol & {$[43,60]$} \\
\hline & 6-Gingerol & {$[43,60]$} \\
\hline & Capsiate & {$[61]$} \\
\hline & 1,4-Cineol & {$[62]$} \\
\hline \multirow[t]{5}{*}{ Inhibitors } & Isovelleral & {$[40]$} \\
\hline & HC-030031 & {$[63]$} \\
\hline & Chembridge-5861528 & {$[64]$} \\
\hline & AP-18 & {$[49]$} \\
\hline & A-967079 & {$[65]$} \\
\hline
\end{tabular}


Table 1 (continued)

\begin{tabular}{|c|c|c|}
\hline Class of compound & Compound & Reference \\
\hline & AZ868 & {$[66]$} \\
\hline & ADM_09 & [67] \\
\hline & Camphor & {$[68]$} \\
\hline & 1,8-Cineol & {$[62]$} \\
\hline \multirow[t]{5}{*}{ Bimodal modulators } & Borneol & [69] \\
\hline & AMG5445 (inhibits human/activates rat) & {$[70]$} \\
\hline & $\begin{array}{l}\text { Menthol (activates human/concentration } \\
\text { dependently activates or inhibits } \\
\text { mouse/no effect on Drosophila) }\end{array}$ & [71] \\
\hline & Caffeine (inhibits human/activates mouse) & {$[72]$} \\
\hline & CMP1 (inhibits human/activates rat) & [73] \\
\hline
\end{tabular}

Fig. 1 Predicted structural features of TRPA1 with putative position of critical residues involved in human TRPA1 modulation by compounds. The TRPA1 subunit, which has six transmembrane domains (TM), a pore-forming region between TM5 and TM6, and many ankyrin repeats (indicated by ovals) in the cytoplasmic $\mathrm{N}$-terminal region [77], assembles into tetramers to form a cation channel. Collectively, indicated residues (indicated by filled circles) are reported to be important for TRPA1 activation or inhibition by several compounds [30-33, $69,71,73,78-80]$
TRPA1

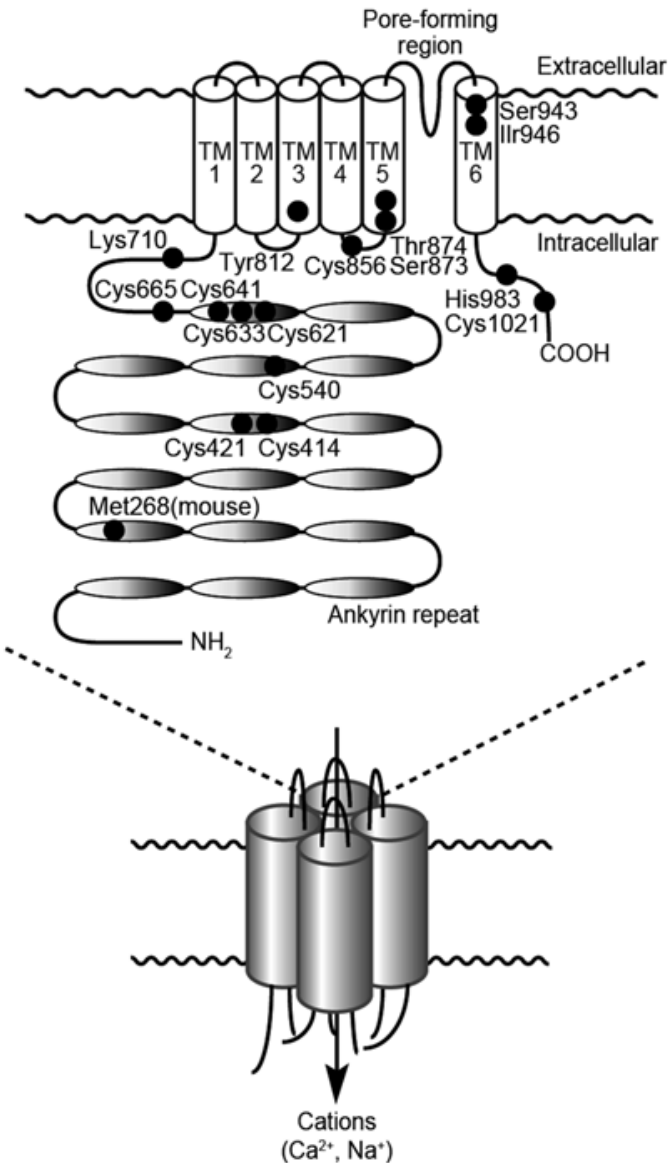


seem also to be critical for TRPA1 activation by other exogenous compounds, including irritants (tear gases, such as 2-chloroacetophenone [39, 81], and $\alpha, \beta$ unsaturated carbonyl-containing compounds, such as methylvinylketone [40, 82]), some plant constituents (umbellulone [41], ligustilide [42], hydroxy- $\alpha$-sanshool $(\alpha-\mathrm{SOH})$ and 6-shogaol [43]), and others (the cyclooxygenase-2 inhibitor etodolac [44], the anti-diabetic drug glibenclamide [45], the gold-containing disease-modifying anti-rheumatic drug auranofin [46], and CMP1 (4-methyl- $N$-[2,2,2-trichloro-1(4-nitro-phenylsulfanyl)-ethyl]-benzamide) [73]). Therefore, TRPA1 is unarguably a receptor for exogenous oxidative/electrophilic compounds.

TRPA1 is also modified via oxidative cysteine modification by endogenous oxidants and electrophiles. TRPA1 is activated by $\mathrm{H}_{2} \mathrm{O}_{2}$ [17, 32, 48, 83], hypochlorite [17], ozone [84], and the ROS generated by ultraviolet light [85]. In addition to ROS, TRPA1 is also activated by RNS such as NO [32, 83, 86] and peroxynitrite [83]. Functional characterization of site-directed mutants of TRPA1 collectively demonstrates that specific cytoplasmic N-terminal cysteine residues and a lysine residue (Cys421, Cys621, Cys641, Cys665, and Lys710 in human TRPA1) are the primary targets of ROS and RNS [17, 32, 86].

In addition to ROS and RNS, lipid peroxidation products such as 4-hydroxy-2nonenal, 4-hydroxyhexenal, 4-oxo-2-nonenal, nitrooleic acid, and 15-deoxy- $\Delta^{12,14}$ prostaglandin $\mathrm{J}_{2}\left(15 \mathrm{~d}-\mathrm{PGJ}_{2}\right)$ activate TRPA1 channels through oxidative modification of the cysteine residues [32, 47-49, 56, 63, 87]. Labeling experiments using biotinylated $15 \mathrm{~d}-\mathrm{PGJ}_{2}$ demonstrated that Cys621 mediates the binding of $15 \mathrm{~d}-\mathrm{PGJ}_{2}$ to human TRPA1 [32]. Another electrophilic dicarbonyl compound, methylglyoxal (MG), which is believed to be associated with the development of diabetic neuropathy, also activates TRPA1 by hemithioacetal formation [50, 51]. Taken together, we can surmise that endogenous electrophilic products activate TRPA 1 channels by cysteine oxidation.

\section{Modulation of Trpa1 by Other Activators and Inhibitors}

Various non-electrophilic activators and inhibitors have also been demonstrated to modulate TRPA1 (Table 1). For example, icilin, 2-aminoethyl diphenylborinate, and carvacrol are compounds with no obvious reactivity toward cysteine residues and activate TRPA1 in a way that is not disrupted by cysteine mutations [30, 31, 81]. TRPA1 is also activated by non-reactive compounds including non-steroidal antiinflammatory drugs, such as flufenamic acid [54]; general anesthetics, such as isoflurane [55]; and farnesyl thiosalicylic acid (FTS) [56]. The chloride channel blocker NPPB (5-nitro-2-(3-phenylpropylamino)benzoic acid) activates TRPA1, and a structure-activity relationship study using a group of NPPB analogs indicates that its phenylalkane, carboxylic, and nitro groups are critical for its activation of TRPA1 [57]. NPPB and FTS are suggested to have similar molecular mechanisms of action at TRPA1. Thymol, 2,6-diisopropylphenol (propofol), and related simple alkyl phenols also activate TRPA1 [53]. TRPA1 is also activated by polyunsaturated fatty acids, which should contain at least three double bonds and 18 carbon atoms, such 
as docosahexaenoic acid (DHA) [58], and by arachidonic acid and its derivatives [59]. 6-Paradol and 6-gingerol activate TRPA1, whereas the non-TRPA1 agonist capsaicin does not, suggesting that a phenol core of these compounds is not sufficient to confer TRPA1 activation [43, 60]. Moreover, capsiate, a non-pungent capsaicin analog, also activates TRPA1 through a mechanism distinct from cysteine and histidine modification [61]. Therefore, TRPA1 activation by non-reactive compounds is dependent on their chemical structures rather than cysteine oxidation.

Inhibitors such as the synthetic compounds HC-030031, Chembridge-5861528 (a derivative of HC-030031), AP-18, A-967079 (a derivative of AP-18), AMG5445, and AZ868 have been developed for TRPA1 [64, 66, 70, 88-93]. Another, ADM_09, is an antagonist of TRPA1 with a putative dual-binding mode of action, which involves the synergic combination of $\mathrm{Ca}^{2+}$-mediated binding of the carnosine group and disulfide formation by its lipoic acid group [67]. Camphor and 1,8-cineol are naturally occurring inhibitors of human TRPA1, but 1,4-cineol is an activator [62]. Borneol is a more effective natural inhibitor than camphor and 1,8-cineol, and the hydroxyl group of borneol is suggested to contribute to its inhibitory action [69].

Several compounds have species-specific modulatory effects on TRPA1. AMG5445 inhibits human TRPA1, but activates rat TRPA1 [70]. The pharmacological profile of the human and rhesus monkey TRPA1 is relatively distinct from mouse and rat TRPA1 [94]. Importantly, findings of species-specific effects have helped to identify the critical region that determines TRPA1 modulation (Fig. 1). Menthol is known to be a bimodal modulator of mouse TRPA1, whereas it does not inhibit human TRPA1, and Drosophila TRPA1 is insensitive to menthol [71]. Chimera and mutagenesis studies indicate that specific residues within TM5 (notably Ser876 and Thr877 of mouse TRPA1, corresponding to Ser873 and Thr874 of human TRPA1) are critical for menthol responsiveness. Furthermore, the region from TM5 to TM6 in mouse and human TRPA1 is the critical domain determining the inhibitory effects of menthol. The same two residues (Ser and Thr within TM5) are also critical for the sensitivity of TRPA1 to AMG5445, AP-18, and A-967079 [65, 71]. DHA sensitivity is limited to human and mouse TRPA1; Drosophila TRPA1 does not respond to DHA [58]. Neither the cytoplasmic N-terminal region nor TM5 of TRPA1 is directly involved in DHA sensing.

Caffeine, which is not a reactive chemical reagent, activates mouse TRPA1, but suppresses human TRPA1 [72]. A mutation of Met268 in the N-terminal cytoplasmic region of mouse TRPA1 to the human form (Pro) changes caffeine action from activation to suppression [79]. An electrophilic compound, CMP1, a structural ana$\log$ of AMG5445, inhibits human TRPA1 and activates rat TRPA1 via modification of human Cys621 and rat Cys622, respectively [73, 95]. The specific mutations Ala946Ser and Met949Ile in the upper portion of the TM6 region of rat TRPA1 change the effect of CMP1 from activatory to inhibitory. Therefore, these studies demonstrate that specific regions and residues within TRPA1 determine the TRPA1 modulatory activity of non-electrophilic compounds, and that the key domains/ residues vary between compounds. Furthermore, while direct physical interaction of non-electrophilic compounds with TRPA1 is likely to be critical for modulation, it is unclear whether or not these critical sites are involved in binding. 
There have been other studies regarding chemical structures important in molecular recognition of activators by TRPA1. Isovelleral, a fungal natural product, which contains an $\alpha, \beta$-unsaturated aldehyde moiety, activates TRPA1 independently of cysteine oxidation [40]. A major compound in extra-virgin olive oil, oleocanthal (OC), is an electrophile that does not require cysteine residues to activate TRPA1 [52]. A structure-activity relationship study using synthetic OC analogs indicated that OC requires both aldehyde groups to activate TRPA1. The mouse Cys622Ser TRPA1 mutant is still sensitive to umbellulone, albeit less so than wild-type TRPA1 [41]. Zhong et al. suggest that umbellulone is a mechanistically hybrid activator, apparently combining covalent interaction at a reactive cysteine with noncovalent interaction with a second site on TRPA1 [41]. Thus, chemical structure recognition by TRPA1, a clearly distinct mechanism from cysteine oxidation, is supposed to be important even for TRPA1 activation by some specific electrophiles.

\section{Subtype-Selective S-Nitrosylation by a Novel Nitrosamine}

Protein $S$-nitrosylation, the covalent attachment of an NO moiety to the sulfur atom of cysteine residues to form $S$-nitrosothiol, regulates various protein functions to mediate NO bioactivity [96]. Receptor-activated (TRPC5, TRPC1, and TRPC4) and thermosensor (TRPV1, TRPV3, TRPV4, and TRPA1) TRP channels are activated by exogenous NO-releasing donors through $S$-nitrosylation [29, 32], but with very limited TRP subtype selectivity. Recently, this problem was partly solved with our finding that the 7-azabenzobicyclo[2.2.1] heptane (ABBH) $N$-nitrosamine selectively activates TRPA1 through transnitrosylation [80].

Although protein $S$-nitrosylation is widely accepted, questions regarding target selectivity of $S$-nitrosylation signaling are incompletely understood [97]. NO is produced in vivo by only three NO synthase (NOS) isoforms [98], and NO is reactive and diffusible within cells. Binding of NOS to targets or their adaptors has been demonstrated at select sites of nitrosylation reactions, but there are many $S$-nitrosylated proteins $(>1,000)[96,99,100]$. Recent studies have identified that protein-protein transnitrosylation, the transfer of the NO group from one protein to another in the absence of apparent NO release, is a potentially important targeting pathway [99, 101, 102]. Transnitrosylation is exemplified by transnitrosylation of X-linked inhibitor of apoptosis by SNO-caspase-3 in apoptotic cell death [103-106]. Here, a binding interaction between the two proteins is also required for transnitrosylation, because a binding-deficient mutant of one protein abrogates this protein-protein transnitrosylation $[105,106]$.

In our effort to develop transnitrosylation-based subtype-selective activators of TRP channels, it was necessary that we first identify a synthetic NO donor that has only transnitrosylative reactivity. However, $\operatorname{SNAP}(S$-nitroso- $N$-acetyl-DL-penicillamine) and NOR3 $(( \pm)-(E)$-4-ethyl-2-[(E)-hydroxyimino]-5-nitro-3-hexenamide) are NO-releasing donors. $S$-Nitrosoglutathione is known to be a biological transnitrosylating agent, but also actively releases NO [107, 108]. In contrast, the ABBH 


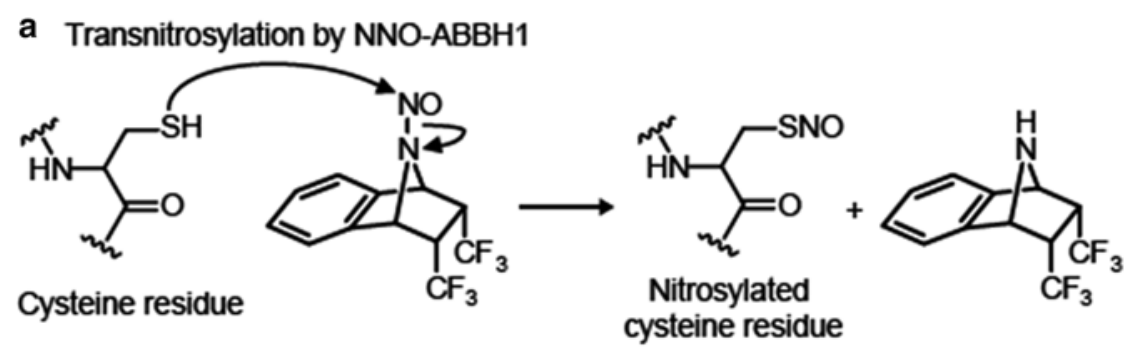

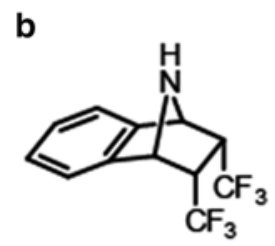

$\mathrm{NH}-\mathrm{ABBH}$

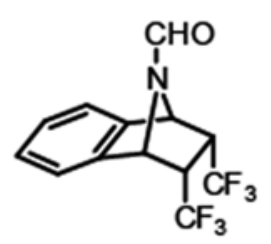

NCHO-ABBH

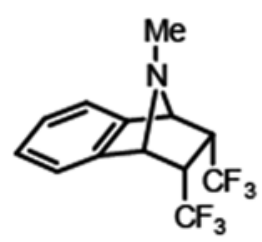

NMe-ABBH

Fig. 2 Selective S-nitrosylation of human TRPA1 by a novel N-nitrosamine. (a) Chemical mechanism underlying the transnitrosylating action of NNO-ABBH1 on protein thiol group. (b) Chemical structures of non-electrophilic analogs of NNO-ABBH1

$N$-nitrosamines constitute a new class of $\mathrm{NO}$ donors that, at physiological $\mathrm{pH}$ and temperature, transnitrosylate thiols to generate $S$-nitrosothiols without releasing NO [109-111]. Surprisingly, our intracellular $\mathrm{Ca}^{2+}$-imaging measurements have demonstrated that $N$-nitroso-2-exo,3-exo-ditrifluoromethyl-7-azabenzobicyclo[2.2.1] heptane (NNO-ABBH1) induces robust $\mathrm{Ca}^{2+}$ influx via recombinant human TRPA1 channels, but not via other SNAP-activated TRP channels, suggesting that NNOABBH1 selectively $S$-nitrosylates TRPA1 [80] (Fig. 2). SNAP $S$-nitrosylates both TRPA1 and TRPV1, but NNO-ABBH1 $S$-nitrosylates only TRPA1. Importantly, TRPA1 activation by NNO-ABBH1 is suppressed by specific cysteine mutations but not by NO scavenging, indicating that transnitrosylation underlies the activation of TRPA1 by NNO-ABBH1. This is supported by a positive correlation of N-NO bond reactivity and TRPA1-activating potency in a congeneric series of ABBH $N$-nitrosamines. Cys540, Cys641, and Cys665 of human TRPA1 are involved in its modification by NNO-ABBH1. Because Cys641 and Cys665 are also required for responsiveness to SNAP [32, 86], Cys540 may be a unique target for NNO-ABBH1.

Several non-electrophilic analogs of NNO-ABBH1 $-\mathrm{N}-\mathrm{H}$ (NH-ABBH), $N$-formyl (NCHO-ABBH), and $N$-methyl (NMe-ABBH) (Fig. 2)—also activated TRPA1 but less potently than NNO-ABBH1. They also did not cause $S$-nitrosylation of TRPA1, and their activity was not affected by cysteine mutation of TRPA1. Interestingly, the NMe-ABBH sensitivity of TRPA1 was significantly enhanced by SNAP at a subthreshold concentration $(10 \mu \mathrm{M})$, supporting the idea that TRPA1 activation by these non-electrophilic analogs may be subject to positive synergistic 
interactions between nitrosylation and molecular recognition. Thus, NNO-ABBH1 may be a hybrid activator. It is reported that a non-electrophilic TRPA1 activator flufenamic acid synergistically potentiates the activation of TRPA1 by AITC [54]. Also, umbellulone has been proposed to activate TRPA1 by combining covalent interaction at a reactive cysteine with noncovalent interaction with a second site on TRPA1 [41]. In contrast to TRPA1, TRPC5 and TRPV1 failed to respond to NMeABBH. Molecular recognition of chemical groups other than NO may explain the subtype-selective activation of TRPA1 by these compounds.

Despite evidence of synergistic effects between cysteine trans-nitrosylation and molecular recognition of the non-electrophilic moiety, it remains unclear how the transnitrosylation site and the non-electrophilic molecular recognition site converge in TRPA1. Also, it is unknown whether NNO-ABBH1 and other non-electrophilic analogs have bimodal and/or species-specific effects on TRPA1. Further detailed studies into TRPA1 modulation by ABBH $N$-nitrosamines will provide a basis for developing new drugs selectively targeting $S$-nitrosylation of TRPA1. In addition, these studies will be expanded toward the development of selective transnitrosylating modulators of other proteins.

\section{TRPC Channels as Therapeutic Targets for Heart Failure}

\section{Structure and Function of TRPC Channels}

Seven mammalian homologs (TRPC1-C7) have so far been identified and expressed in the heart. While TRPC4 and TRPC5 share about $65 \%$ amino acid homology in their group, TRPC3, TRPC6, and TRPC7 display the greatest homology covering $\sim 75 \%$ of the amino acid sequence [112]. TRPC1, TRPC3, and TRPC6 have been identified to play a role in cardiovascular diseases, especially pathological cardiac hypertrophy and heart failure.

The mammalian TRPC proteins include three to four ankyrin repeats and coiledcoil domain in the cytoplasmic $\mathrm{N}$-terminal sequence that are essential for tetrameric channel assembly, and six putative transmembrane domains, and amino acid sequence identity ( $\geq 30 \%$ ) over the N-terminal $\sim 750-900$ amino acids in the internal C-terminus, which includes the TRP box motif with the conserved EWKFAR residues and another coiled-coil motif. The higher-order structure of TRPC3 channels was recently solved using single particle cryo-electron microscopy [113]. The ice structure is lace-like and very open, with a very large overall volume. The TRPC channels appear to form assemblies of homotetramers or heterotetramers at least within given structural subfamilies; i.e., TRPC1/4/5 or TRPC3/6/7 [114]. TRPC1, TRPC4, and TRPC5 channels are activated by inositol-1,4,5-trisphosphate $\left(\mathrm{IP}_{3}\right)$-dependent mechanisms, while TRPC3, TRPC6, and TRPC7 are directly activated by diacylglycerol (DAG) independently of the store depletion-induced mechanism [115]. Meanwhile, it is reported that the direct interaction of TRPC3 
with $\mathrm{IP}_{3} \mathrm{R}$ or ryanodine receptor $(\mathrm{RyR})$ is required for TRPC3 activation $[116,117]$ and the DAG-induced activation of native TRPC7 in DT40 B lymphocytes [118]. The N-termini and C-termini serve as the sites for protein scaffolding, including $\mathrm{IP}_{3} \mathrm{R}$, RyR, caveolin [119], phospholipase C (PLC) $\gamma[120,121]$, protein kinase C $\beta$ [122], and $\mathrm{Na}^{+} / \mathrm{H}^{+}$exchanger regulatory factor (NHERF) 1 [123]. These interactions are often found to regulate subcellular localization of the respective TRPC proteins. For example, interaction of the ankyrin domain in TRPC6 with the ring finger protein (RNF24) is essential for retention of TRPC6 in the Golgi apparatus [124], and association of TRPC3 at the N-terminus with vesicle-associated membrane protein (VAMP) 2 is required for vesicular trafficking of TRPC3 [125].

TRPC1 is considered unique because no other family member shares highsequence homology. TRPC1 first emerged as a candidate subunit of SOCs [126-129]. Recently, our study has implicated the critical involvement of TRPC1 in coordination with elementary $\mathrm{Ca}^{2+}$ signaling events that promote functional coupling between the ER and plasma membrane in receptor-induced $\mathrm{Ca}^{2+}$ signaling [130]. Thus, TRPC1 may not only function as a $\mathrm{Ca}^{2+}$-permeable channel-forming subunit, but also as an accessory protein to form the $\mathrm{Ca}^{2+}$ signaling complex.

The activation mechanism of TRPC channels is not only linked to PLC activation by receptor stimulation, but also linked to physical stimulations such as mechanical stretch, hypoxia, and oxidative stress [131]. TRPC1 and TRPC6 have been suggested to be a component of the tarantula toxin-sensitive mechanosensitive cation channels $[132,133]$. For example, the excessive mechanical stress-induced muscle contractility in myocytes with Duchenne muscular dystrophy was blunted by inhibition or deletion of TRPC6 [134]. On the other hand, intracellular lipid mediators, such as DAG and 12-hydroxy-eicosatetraenoic acid (12-HETE), reportedly mediate TRPC6 channel activation induced by oxidative stress [135] and mechanical stretch [136]. Thus, TRPC6 protein signaling complex, including TRPC1 and TRPC3, may function as both mechanosensitive and mechanoactivated cation channels in the cardiovascular system.

\section{Role of TRPC Channels in Pathological Cardiac Remodeling}

Cardiovascular disease is a leading cause of morbidity and mortality, accounting for more than a quarter of all deaths worldwide. Especially, heart failure is a final stage of all cardiovascular diseases, and the 5-year survival rate after diagnosis is less than $50 \%$ [137]. Several drugs that modulate neurohumoral activation, such as $\beta$-adrenergic receptor antagonists, angiotensin-converting enzyme (ACE) inhibitors, angiotensin (Ang) type 1 receptor (AT1R) antagonists, and mineral corticoid receptor antagonists, have been introduced for the treatment of heart failure [138]. Treatment with these drugs has been shown to improve the prognosis in patients with heart failure with reduced systolic function, but the mortality for heart failure still remains unacceptably high. Thus, additional approaches are greatly required as the prevalence of cardiovascular diseases continues to rise and exact a huge societal cost. 
Induction of pathologic remodeling (i.e., structural and morphological changes of organs) and organ dysfunction is a common prominent feature of these disorders that is mediated by excessive and sustained neurohumoral and mechanical stimulation. In the cardiovascular system, the TRPC family has been particularly found to play a role in cardiovascular diseases. As heart failure is developed through hypertrophy [139], many studies have investigated the mechanisms of hypertrophy [140]. TRPC1, TRPC3, and TRPC6 are often upregulated in several rodent models of cardiac hypertrophy, and their inhibition ameliorates the associated cardiovascular dysfunction [141]. In human heart failure, upregulation of TRPC5 and TRPC6 was observed [34, 142]. Although the subtype of upregulated TRPC channels at hypertrophy may differ between mice and humans, these findings suggest that the expression of TRPC channels is increased on hypertrophy, and upregulated TRPC may activate local $\mathrm{Ca}^{2+}$ signaling essential for the progression of pathological cardiac remodeling and failure.

TRPC expression is regulated by the $\mathrm{Ca}^{2+}$-dependent protein phosphatase, calcineurin, and its downstream target, nuclear factor of activated T cells (NFAT) $[143,144]$. Increases in the frequency or amplitude of $\mathrm{Ca}^{2+}$ transients evoked by $\mathrm{Ca}^{2+}$ influx-induced $\mathrm{Ca}^{2+}$ release in excitable cardiomyocytes is thought to encode signals for induction of hypertrophic gene expression [145, 146]. Activation of TRPC channels induces local $\mathrm{Ca}^{2+}$ signaling through an increase in the frequency of $\mathrm{Ca}^{2+}$ transient via $\mathrm{Na}^{+}$influx-dependent membrane depolarization and/or direct $\mathrm{Ca}^{2+}$ influx, which leads to NFAT transcriptional activation through calcineurindependent dephosphorylation and nuclear translocation of NFAT. TRPC3-mediated $\mathrm{Ca}^{2+}$ influx has been shown to regulate hypertrophic gene expression without affecting cardiac beating and cell size [147]. As the promoter region of the TRPC6 gene contains NFAT binding sites, activation of plasma membrane TRPC channels may serve as a positive-feedback mechanism to amplify TRPC-mediated $\mathrm{Ca}^{2+}$ signaling in the heart [34]. In addition, NFAT transcriptional activation requires association of co-factor(s) with NFAT, and TRPC6 upregulation is also mediated by stressactivated protein kinases (c-Jun $\mathrm{NH}_{2}$-terminal kinase and p38 mitogen-activated protein kinase) upon receptor stimulation in cardiac fibroblasts [148, 149]. Thus, multiple transcriptional pathways including the calcineurin-NFAT pathway have been linked to maladaptive cardiovascular remodeling via TRPC upregulation.

Mice with cardiomyocyte-specific overexpression of TRPC 3 and TRPC6 show heightened sensitivity to mechanical stress and increased expression of a sensitive marker for pathological hypertrophy $[34,150]$. In contrast, pressure overloadinduced cardiac hypertrophy is suppressed by double deletions of TRPC $3 / 6$ genes in C57BL6/J background mice, although single deletion of TRPC3 and TRPC6 genes never suppresses cardiac hypertrophy [151]. As TRPC3 and TRPC6 form heteromultimer channels and regulate agonist- and mechanical stretch-induced hypertrophic growth of rat neonatal cardiomyocytes [35] and mice lacking TRPC6 were reported to have mRNA upregulation for TRPC3 [152], TRPC3 and TRPC6 proteins may compensatively work with each other. TRPC6 is abundantly expressed 
in cardiac fibroblasts, and fibroblasts lacking the TRPC6 gene were refractory to transdifferentiation [149]. TRPC6 gene-deleted mice show impaired dermal and cardiac wound healing after injury, suggesting an obligate function for TRPC6 and calcineurin in promoting myofibroblast differentiation.

TRPC1 is also thought to play a pathologic role in the heart, with increased expression observed in rodent hearts with cardiomyocyte hypertrophy. Ohba et al. first reported the potential involvement of TRPC1 channels in pressure overloadinduced hypertrophy [153]. Among TRPC1, TRPC3, TRPC5, and TRPC6, TRPC1 expression was increased in abdominal aortic-banded rats. Endothelin-1 (ET-1) stimulation resulted in the increased expression of brain natriuretic protein (BNP), atrial natriuretic factor (ANF), and TRPC1 as well as an increased cell surface area in neonatal myocytes. ET-1 stimulation also increased $\mathrm{Ca}^{2+}$ entry possibly through TRPC channels. Knockdown of TRPC1 with siRNA prevented Gq-coupled receptor-stimulated hypertrophic responses. Mice with global TRPC1 gene deletion show less cardiac hypertrophy and left ventricular dysfunction in response to pressure overload or neurohormonal stimulation in comparison with wild-type 129Sv background mice [154]. Although it is still unclear whether TRPC1 gene deletion never suppresses physiological (adaptive) hypertrophy in vivo, TRPC1 might be also a therapeutic target for heart failure.

\section{Negative Feedback Mechanism in TRPC Channels}

Phosphorylation of TRPC $3 / 6$ proteins by protein kinase $\mathrm{C}(\mathrm{PKC})$, protein kinase A (PKA), and protein kinase $\mathrm{G}$ (PKG) has been widely accepted as a major posttranslational modification that negatively regulates TRPC channel activity. PKG can directly phosphorylate human TRPC3 at Thr-11 and Ser-263, and human TRPC6 at Thr-70 and Ser-322. PKG is activated by NO, atrial natriuretic peptide (ANP), or inhibition of phosphodiesterase (PDE)-5, each of which negatively regulates pathological cardiac hypertrophy. The physiological importance of PKG-dependent negative regulation of TRPC6 channel activity by NO was originally identified as a mechanism of endothelium-dependent vasodilation [155]. As PKA and PKG recognize a similar substrate sequence, PKA-dependent phosphorylation of rodent TRPC6 at Thr-69 was also revealed to serve as an endothelium-independent vasodilation [156]. Increased PKG activity attenuates $\mathrm{Ca}^{2+} /$ calcineurin-dependent cardiomyocyte hypertrophy induced by receptor stimulation and mechanical stretch, and mutation of the PKG phosphorylation site on TRPC6 canceled this inhibitory effect [157]. In contrast, decreased cGMP/PKG signaling by deletion of the guanylate cyclase (GC)-A gene was associated with development of spontaneous cardiac hypertrophy through TRPC $3 / 6$ channel activation [158]. Actually, this hypertrophy was attenuated by treatment with Pyr2, an inhibitor of all TRPC channels. 


\section{Suppression of Pathological Cardiac Hypertrophy by TRPC3/6 Inhibition}

Several reagents that inhibit TRPC3/6 channel activity have been shown to suppress cardiac hypertrophy in vivo and in vitro. For example, $\alpha 1$ adrenergic receptorstimulated hypertrophic responses were blocked by 2-aminoethoxydiphenylborane (2-APB) and N-\{4-[3,5-bis(trifluoromethyl)-1H-pyrazol- 1yl]phenyl $\}$-4-methyl1,2,3-thiadiazole-5-carboxamide (BTP2; also called Pyr2), but not by verapamil, a voltage-dependent L-type $\mathrm{Ca}^{2+}$ channel blocker [142]. Indirect inhibition of TRPC3/6 channel activities by PDE-5 inhibitors [159] and ANP [158] can also suppresses pathological hypertrophy through phosphorylation of TRPC6 at Thr69. Mori developed a pyrazole compound, Pyr3, which selectively inhibits TRPC3 channel activity with an $\mathrm{IC}_{50}$ value of $0.7 \mu \mathrm{M}$ [36]. Interestingly, Pyr3 showed more potent inhibitory effects on mechanical stretch-induced NFAT activation and hypertrophic growth of rat neonatal cardiomyocytes, suggesting that Pyr3 is more selective for native TRPC 3/6 heteromultimer channels in the heart. Indeed, left ventricular dilation and dysfunction induced by pressure overload [36] or genetic deletion of muscle LIM protein [160] were actually reduced by a low concentration $(0.1 \mathrm{mg} / \mathrm{kg} /$ day) of Pyr3 treatment. Moreover, Pyr3 treatment also suppressed oxidative stress and cardiac fibrosis in mouse hearts with dilated cardiomyopathy, and mechanical stretch-induced production of ROS in rat cardiomyocytes. Two recently identified selective TRPC3/6 inhibitors, GSK2332255B and GSK2833503A (IC (I0 $_{3}, 3-21 \mathrm{nM}$ against TRPC3 and TRPC6), also inhibited ET-1-induced hypertrophic responses in adult cardiac myocytes [151]. These findings strongly suggest that TRPC3 and TRPC6 are emerging as critical targets in the development of drugs relevant to therapies for pathological cardiac remodeling and chronic heart failure.

\section{Conclusion}

Because TRPA1 mediates neuropathic pain, vascular dilation, and other functions, it has the potential to be an excellent drug target. Therefore, it is important to understand the mechanisms of both activation and inhibition of TRPA1 by small molecules. Recent studies have revealed that TRPA1 modulation by electrophiles is through cysteine oxidation, and that molecular recognition of chemical structures is a key determinant of TRPA1 modulation not only by non-electrophilic compounds, but also by some specific electrophiles. A novel ABBH $N$-nitrosamine induces selective $S$-nitrosylation of TRPA1 probably through synergistic processes of cysteine oxidation and molecular recognition of the non-electrophilic moiety. However, molecular bases of TRPA1 modulation by non-electrophilic compounds are very poorly understood. Further studies are required to delineate the entire mechanism. Similarly, further research is needed to define in detail the molecular mechanisms by which chemical ligands induce the activation of other TRP channels, such as 
TRPV1 and TRPM8 [10, 161]. This might support our understanding of TRPA1 mechanisms. TRPA 1 channel activity is also modulated by $\mathrm{Ca}^{2+}$, receptor stimulation, $\mathrm{pH}$, osmotic pressure, and temperature [60, 162-168], so a better understanding of the complexities of its modulation is critical to the development of novel TRPA1-specific drugs. It will also improve our appreciation of the physiological and pathological functions of TRPA1.

In terms of TRPCs, a growing body of evidence has suggested that direct or indirect inhibition of TRPC $3 / 6$ channel activity improves pathological cardiac remodeling and heart failure in mice, although the molecular mechanisms underlying regulation of transition of the heart from adaptation to maladaptation by TRPC $3 / 6$ channels are still uncovered. A pyrazole-derivative compound is also reported to inhibit SOCs as well as TRPC3 [169], but our findings strongly suggest that a pyrazole-derivative compound (especially Pyr3) will become a promising seed for the treatment of chronic heart failure.

Open Access This chapter is distributed under the terms of the Creative Commons Attribution Noncommercial License, which permits any noncommercial use, distribution, and reproduction in any medium, provided the original author(s) and source are credited.

\section{References}

1. Montell C, Rubin GM (1989) Molecular characterization of the Drosophila trp locus: a putative integral membrane protein required for phototransduction. Neuron 2(4):1313-1323

2. Clapham DE (2003) TRP channels as cellular sensors. Nature 426(6966):517-524. doi:10.1038/nature02196

3. Montell C (2005) The TRP superfamily of cation channels. Sci STKE 2005(272):re3. doi:10.1126/stke.2722005re3

4. Venkatachalam K, Montell C (2007) TRP channels. Annu Rev Biochem 76:387-417. doi:10.1146/annurev.biochem.75.103004.142819

5. Patapoutian A, Peier AM, Story GM, Viswanath V (2003) ThermoTRP channels and beyond: mechanisms of temperature sensation. Nat Rev Neurosci 4(7):529-539. doi:10.1038/nrn1141

6. Clapham DE, Julius D, Montell C, Schultz G (2005) International Union of Pharmacology. XLIX Nomenclature and structure-function relationships of transient receptor potential channels. Pharmacol Rev 57(4):427-450. doi:10.1124/pr.57.4.6

7. Voets T, Talavera K, Owsianik G, Nilius B (2005) Sensing with TRP channels. Nat Chem Biol 1(2):85-92. doi:10.1038/nchembio0705-85

8. Christensen AP, Corey DP (2007) TRP channels in mechanosensation: direct or indirect activation? Nat Rev Neurosci 8(7):510-521. doi:10.1038/nrn2149

9. Nilius B, Owsianik G, Voets T, Peters JA (2007) Transient receptor potential cation channels in disease. Physiol Rev 87(1):165-217. doi:10.1152/physrev.00021.2006

10. Vriens J, Nilius B, Vennekens R (2008) Herbal compounds and toxins modulating TRP channels. Curr Neuropharmacol 6(1):79-96. doi:10.2174/157015908783769644

11. Wu LJ, Sweet TB, Clapham DE (2010) International Union of Basic and Clinical Pharmacology. LXXVI Current progress in the mammalian TRP ion channel family. Pharmacol Rev 62(3):381-404. doi:10.1124/pr.110.002725

12. Numata T, Kiyonaka S, Kato K, Takahashi N, Mori Y (2011) Activation of TRP channels in mammalian systems. In: Zhu MX (ed) TRP channels. CRC Press, Boca Raton 
13. Santoni G, Farfariello V (2011) TRP channels and cancer: new targets for diagnosis and chemotherapy. Endocr Metab Immune Disord Drug Targets 11(1):54-67

14. Gees M, Owsianik G, Nilius B, Voets T (2012) TRP channels. Compr Physiol 2(1):563-608. doi:10.1002/cphy.c110026

15. Julius D (2013) TRP channels and pain. Annu Rev Cell Dev Biol 29:355-384. doi:10.1146/ annurev-cellbio-101011-155833

16. Sousa-Valente J, Andreou AP, Urban L, Nagy I (2014) Transient receptor potential ion channels in primary sensory neurons as targets for novel analgesics. $\mathrm{Br} \mathrm{J}$ Pharmacol 171(10):2508-2527. doi:10.1111/bph.12532

17. Bessac BF, Jordt SE (2008) Breathtaking TRP channels: TRPA1 and TRPV1 in airway chemosensation and reflex control. Physiology 23:360-370. doi:10.1152/physiol.00026.2008

18. Miller BA, Zhang W (2011) TRP channels as mediators of oxidative stress. Adv Exp Med Biol 704:531-544. doi:10.1007/978-94-007-0265-3_29

19. Kozai D, Ogawa N, Mori Y (2014) Redox regulation of transient receptor potential channels. Antioxid Redox Signal 21(6):971-986. doi:10.1089/ars.2013.5616

20. Simon F, Varela D, Cabello-Verrugio C (2013) Oxidative stress-modulated TRPM ion channels in cell dysfunction and pathological conditions in humans. Cell Signal 25(7):1614-1624. doi:10.1016/j.cellsig.2013.03.023

21. Droge W (2002) Free radicals in the physiological control of cell function. Physiol Rev 82(1):47-95. doi:10.1152/physrev.00018.2001

22. Brieger K, Schiavone S, Miller FJ Jr, Krause KH (2012) Reactive oxygen species: from health to disease. Swiss Med Wkly 142:w13659. doi:10.4414/smw.2012.13659

23. Hara Y, Wakamori M, Ishii M, Maeno E, Nishida M, Yoshida T, Yamada H, Shimizu S, Mori E, Kudoh J, Shimizu N, Kurose H, Okada Y, Imoto K, Mori Y (2002) LTRPC2 Ca2 +permeable channel activated by changes in redox status confers susceptibility to cell death. Mol Cell 9(1):163-173

24. Yamamoto S, Shimizu S, Kiyonaka S, Takahashi N, Wajima T, Hara Y, Negoro T, Hiroi T, Kiuchi Y, Okada T, Kaneko S, Lange I, Fleig A, Penner R, Nishi M, Takeshima H, Mori Y (2008) TRPM2-mediated Ca2 + influx induces chemokine production in monocytes that aggravates inflammatory neutrophil infiltration. Nat Med 14(7):738-747. doi:10.1038/ nm1758

25. Naziroglu M (2011) TRPM2 cation channels, oxidative stress and neurological diseases: where are we now? Neurochem Res 36(3):355-366. doi:10.1007/s11064-010-0347-4

26. Knowles H, Li Y, Perraud AL (2013) The TRPM2 ion channel, an oxidative stress and metabolic sensor regulating innate immunity and inflammation. Immunol Res 55(1-3):241-248. doi:10.1007/s12026-012-8373-8

27. Aarts M, Iihara K, Wei WL, Xiong ZG, Arundine M, Cerwinski W, MacDonald JF, Tymianski M (2003) A key role for TRPM7 channels in anoxic neuronal death. Cell 115(7):863-877

28. McNulty S, Fonfria E (2005) The role of TRPM channels in cell death. Pflugers Arch: Eur J Physiol 451(1):235-242. doi:10.1007/s00424-005-1440-4

29. Yoshida T, Inoue R, Morii T, Takahashi N, Yamamoto S, Hara Y, Tominaga M, Shimizu S, Sato Y, Mori Y (2006) Nitric oxide activates TRP channels by cysteine S-nitrosylation. Nat Chem Biol 2(11):596-607. doi:10.1038/nchembio821

30. Hinman A, Chuang HH, Bautista DM, Julius D (2006) TRP channel activation by reversible covalent modification. Proc Natl Acad Sci U S A 103(51):19564-19568. doi:10.1073/ pnas.0609598103

31. Macpherson LJ, Dubin AE, Evans MJ, Marr F, Schultz PG, Cravatt BF, Patapoutian A (2007) Noxious compounds activate TRPA1 ion channels through covalent modification of cysteines. Nature 445(7127):541-545. doi:10.1038/nature05544

32. Takahashi N, Mizuno Y, Kozai D, Yamamoto S, Kiyonaka S, Shibata T, Uchida K, Mori Y (2008) Molecular characterization of TRPA1 channel activation by cysteine-reactive inflammatory mediators. Channels 2(4):287-298 
33. Takahashi N, Kuwaki T, Kiyonaka S, Numata T, Kozai D, Mizuno Y, Yamamoto S, Naito S, Knevels E, Carmeliet P, Oga T, Kaneko S, Suga S, Nokami T, Yoshida J, Mori Y (2011) TRPA1 underlies a sensing mechanism for O2. Nat Chem Biol 7(10):701-711. doi:10.1038/ nchembio. 640

34. Kuwahara K, Wang Y, McAnally J, Richardson JA, Bassel-Duby R, Hill JA, Olson EN (2006) TRPC6 fulfills a calcineurin signaling circuit during pathologic cardiac remodeling. J Clin Invest 116(12):3114-3126. doi:10.1172/JCI27702

35. Onohara N, Nishida M, Inoue R, Kobayashi H, Sumimoto H, Sato Y, Mori Y, Nagao T, Kurose H (2006) TRPC3 and TRPC6 are essential for angiotensin II-induced cardiac hypertrophy. EMBO J 25(22):5305-5316. doi:10.1038/sj.emboj.7601417

36. Kiyonaka S, Kato K, Nishida M, Mio K, Numaga T, Sawaguchi Y, Yoshida T, Wakamori M, Mori E, Numata T, Ishii M, Takemoto H, Ojida A, Watanabe K, Uemura A, Kurose H, Morii T, Kobayashi T, Sato Y, Sato C, Hamachi I, Mori Y (2009) Selective and direct inhibition of TRPC3 channels underlies biological activities of a pyrazole compound. Proc Natl Acad Sci U S A 106(13):5400-5405. doi:10.1073/pnas.0808793106

37. Bautista DM, Movahed P, Hinman A, Axelsson HE, Sterner O, Hogestatt ED, Julius D, Jordt SE, Zygmunt PM (2005) Pungent products from garlic activate the sensory ion channel TRPA1. Proc Natl Acad Sci U S A 102(34):12248-12252. doi:10.1073/pnas.0505356102

38. Macpherson LJ, Geierstanger BH, Viswanath V, Bandell M, Eid SR, Hwang S, Patapoutian A (2005) The pungency of garlic: activation of TRPA1 and TRPV1 in response to allicin. Curr Biol: CB 15(10):929-934. doi:10.1016/j.cub.2005.04.018

39. Brone B, Peeters PJ, Marrannes R, Mercken M, Nuydens R, Meert T, Gijsen HJ (2008) Tear gasses CN, CR, and CS are potent activators of the human TRPA1 receptor. Toxicol Appl Pharmacol 231(2):150-156. doi:10.1016/j.taap.2008.04.005

40. Escalera J, von Hehn CA, Bessac BF, Sivula M, Jordt SE (2008) TRPA1 mediates the noxious effects of natural sesquiterpene deterrents. J Biol Chem 283(35):24136-24144. doi:10.1074/ jbc.M710280200

41. Zhong J, Minassi A, Prenen J, Taglialatela-Scafati O, Appendino G, Nilius B (2011) Umbellulone modulates TRP channels. Pflugers Arch: Eur J Physiol 462(6):861-870. doi:10.1007/s00424-011-1043-1

42. Zhong J, Pollastro F, Prenen J, Zhu Z, Appendino G, Nilius B (2011) Ligustilide: a novel TRPA1 modulator. Pflugers Arch: Eur J Physiol 462(6):841-849. doi:10.1007/s00424-011-1021-7

43. Riera CE, Menozzi-Smarrito C, Affolter M, Michlig S, Munari C, Robert F, Vogel H, Simon SA, le Coutre J (2009) Compounds from Sichuan and Melegueta peppers activate, covalently and non-covalently, TRPA1 and TRPV1 channels. Br J Pharmacol 157(8):1398-1409. doi:10.1111/j.1476-5381.2009.00307.x

44. Wang S, Dai Y, Kogure Y, Yamamoto S, Zhang W, Noguchi K (2013) Etodolac activates and desensitizes transient receptor potential ankyrin 1. J Neurosci Res 91(12):1591-1598. doi:10.1002/jnr.23274

45. Babes A, Fischer MJ, Filipovic M, Engel MA, Flonta ML, Reeh PW (2013) The anti-diabetic drug glibenclamide is an agonist of the transient receptor potential Ankyrin 1 (TRPA1) ion channel. Eur J Pharmacol 704(1-3):15-22. doi:10.1016/j.ejphar.2013.02.018

46. Hatano N, Suzuki H, Muraki Y, Muraki K (2013) Stimulation of human TRPA1 channels by clinical concentrations of the antirheumatic drug auranofin. Am J Physiol Cell Physiol 304(4):C354-C361. doi:10.1152/ajpcell.00096.2012

47. Trevisani M, Siemens J, Materazzi S, Bautista DM, Nassini R, Campi B, Imamachi N, Andre E, Patacchini R, Cottrell GS, Gatti R, Basbaum AI, Bunnett NW, Julius D, Geppetti P (2007) 4-Hydroxynonenal, an endogenous aldehyde, causes pain and neurogenic inflammation through activation of the irritant receptor TRPA1. Proc Natl Acad Sci U S A 104(33):13519-13524. doi:10.1073/pnas.0705923104

48. Andersson DA, Gentry C, Moss S, Bevan S (2008) Transient receptor potential A1 is a sensory receptor for multiple products of oxidative stress. J Neurosci: Off J Soc Neurosci 28(10):2485-2494. doi:10.1523/JNEUROSCI.5369-07.2008 
49. Taylor-Clark TE, Ghatta S, Bettner W, Undem BJ (2009) Nitrooleic acid, an endogenous product of nitrative stress, activates nociceptive sensory nerves via the direct activation of TRPA1. Mol Pharmacol 75(4):820-829. doi:10.1124/mol.108.054445

50. Eberhardt MJ, Filipovic MR, Leffler A, de la Roche J, Kistner K, Fischer MJ, Fleming T, Zimmermann K, Ivanovic-Burmazovic I, Nawroth PP, Bierhaus A, Reeh PW, Sauer SK (2012) Methylglyoxal activates nociceptors through transient receptor potential channel A1 (TRPA1): a possible mechanism of metabolic neuropathies. J Biol Chem 287(34):28291-28306. doi:10.1074/jbc.M111.328674

51. Andersson DA, Gentry C, Light E, Vastani N, Vallortigara J, Bierhaus A, Fleming T, Bevan S (2013) Methylglyoxal evokes pain by stimulating TRPA1. PLoS One 8(10):e77986. doi:10.1371/journal.pone.0077986

52. Peyrot des Gachons C, Uchida K, Bryant B, Shima A, Sperry JB, Dankulich-Nagrudny L, Tominaga M, Smith AB 3rd, Beauchamp GK, Breslin PA (2011) Unusual pungency from extra-virgin olive oil is attributable to restricted spatial expression of the receptor of oleocanthal. J Neurosci: Off J Soc Neurosci 31(3):999-1009. doi:10.1523/JNEUROSCI.1374-10.2011

53. Lee SP, Buber MT, Yang Q, Cerne R, Cortes RY, Sprous DG, Bryant RW (2008) Thymol and related alkyl phenols activate the hTRPA1 channel. Br J Pharmacol 153(8):1739-1749. doi:10.1038/bjp.2008.85

54. Hu H, Tian J, Zhu Y, Wang C, Xiao R, Herz JM, Wood JD, Zhu MX (2010) Activation of TRPA1 channels by fenamate nonsteroidal anti-inflammatory drugs. Pflugers Arch: Eur J Physiol 459(4):579-592. doi:10.1007/s00424-009-0749-9

55. Matta JA, Cornett PM, Miyares RL, Abe K, Sahibzada N, Ahern GP (2008) General anesthetics activate a nociceptive ion channel to enhance pain and inflammation. Proc Natl Acad Sci U S A 105(25):8784-8789. doi:10.1073/pnas.0711038105

56. Maher M, Ao H, Banke T, Nasser N, Wu NT, Breitenbucher JG, Chaplan SR, Wickenden AD (2008) Activation of TRPA1 by farnesyl thiosalicylic acid. Mol Pharmacol 73(4):1225-1234. doi: $10.1124 / \mathrm{mol} .107 .042663$

57. Liu K, Samuel M, Ho M, Harrison RK, Paslay JW (2010) NPPB structure-specifically activates TRPA1 channels. Biochem Pharmacol 80(1):113-121. doi:10.1016/j.bcp.2010.03.005

58. Motter AL, Ahern GP (2012) TRPA1 is a polyunsaturated fatty acid sensor in mammals. PLoS One 7(6):e38439. doi:10.1371/journal.pone.0038439

59. Redmond WJ, Gu L, Camo M, McIntyre P, Connor M (2014) Ligand determinants of fatty acid activation of the pronociceptive ion channel TRPA1. PeerJ 2:e248. doi:10.7717/peerj.248

60. Bandell M, Story GM, Hwang SW, Viswanath V, Eid SR, Petrus MJ, Earley TJ, Patapoutian A (2004) Noxious cold ion channel TRPA1 is activated by pungent compounds and bradykinin. Neuron 41(6):849-857

61. Shintaku K, Uchida K, Suzuki Y, Zhou Y, Fushiki T, Watanabe T, Yazawa S, Tominaga M (2012) Activation of transient receptor potential A1 by a non-pungent capsaicin-like compound, capsiate. Br J Pharmacol 165(5):1476-1486. doi:10.1111/j.1476-5381.2011.01634.x

62. Takaishi M, Fujita F, Uchida K, Yamamoto S, Sawada Shimizu M, Hatai Uotsu C, Shimizu M, Tominaga M (2012) 1,8-cineole, a TRPM8 agonist, is a novel natural antagonist of human TRPA1. Mol Pain 8:86. doi:10.1186/1744-8069-8-86

63. Taylor-Clark TE, Undem BJ, Macglashan DW Jr, Ghatta S, Carr MJ, McAlexander MA (2008) Prostaglandin-induced activation of nociceptive neurons via direct interaction with transient receptor potential A1 (TRPA1). Mol Pharmacol 73(2):274-281. doi:10.1124/ mol.107.040832

64. Wei H, Chapman H, Saarnilehto M, Kuokkanen K, Koivisto A, Pertovaara A (2010) Roles of cutaneous versus spinal TRPA1 channels in mechanical hypersensitivity in the diabetic or mustard oil-treated non-diabetic rat. Neuropharmacology 58(3):578-584. doi:10.1016/j. neuropharm.2009.12.001

65. Nakatsuka K, Gupta R, Saito S, Banzawa N, Takahashi K, Tominaga M, Ohta T (2013) Identification of molecular determinants for a potent mammalian TRPA1 antagonist by utilizing species differences. J Mol Neurosci: MN 51(3):754-762. doi:10.1007/s12031-013-0060-2 
66. Vallin KS, Sterky KJ, Nyman E, Bernstrom J, From R, Linde C, Minidis AB, Nolting A, Narhi K, Santangelo EM, Sehgelmeble FW, Sohn D, Strindlund J, Weigelt D (2012) N-1Alkyl-2-oxo-2-aryl amides as novel antagonists of the TRPA1 receptor. Bioorg Med Chem Lett 22(17):5485-5492. doi:10.1016/j.bmcl.2012.07.032

67. Nativi C, Gualdani R, Dragoni E, Di Cesare ML, Sostegni S, Norcini M, Gabrielli G, la Marca G, Richichi B, Francesconi O, Moncelli MR, Ghelardini C, Roelens S (2013) A TRPA1 antagonist reverts oxaliplatin-induced neuropathic pain. Sci Rep 3:2005. doi:10.1038/ srep02005

68. Xu H, Blair NT, Clapham DE (2005) Camphor activates and strongly desensitizes the transient receptor potential vanilloid subtype 1 channel in a vanilloid-independent mechanism. $\mathrm{J}$ Neurosci: Off J Soc Neurosci 25(39):8924-8937. doi:10.1523/JNEUROSCI.2574-05.2005

69. Takaishi M, Uchida K, Fujita F, Tominaga M (2014) Inhibitory effects of monoterpenes on human TRPA1 and the structural basis of their activity. J Physiol Sci: JPS 64(1):47-57. doi:10.1007/s12576-013-0289-0

70. Klionsky L, Tamir R, Gao B, Wang W, Immke DC, Nishimura N, Gavva NR (2007) Speciesspecific pharmacology of Trichloro(sulfanyl)ethyl benzamides as transient receptor potential ankyrin 1 (TRPA1) antagonists. Mol Pain 3:39. doi:10.1186/1744-8069-3-39

71. Xiao B, Dubin AE, Bursulaya B, Viswanath V, Jegla TJ, Patapoutian A (2008) Identification of transmembrane domain 5 as a critical molecular determinant of menthol sensitivity in mammalian TRPA1 channels. J Neurosci: Off J Soc Neurosci 28(39):9640-9651. doi:10.1523/ JNEUROSCI.2772-08.2008

72. Nagatomo K, Kubo Y (2008) Caffeine activates mouse TRPA1 channels but suppresses human TRPA1 channels. Proc Natl Acad Sci U S A 105(45):17373-17378. doi:10.1073/ pnas.0809769105

73. Chen J, Zhang XF, Kort ME, Huth JR, Sun C, Miesbauer LJ, Cassar SC, Neelands T, Scott VE, Moreland RB, Reilly RM, Hajduk PJ, Kym PR, Hutchins CW, Faltynek CR (2008) Molecular determinants of species-specific activation or blockade of TRPA1 channels. J Neurosci: Off J Soc Neurosci 28(19):5063-5071. doi:10.1523/JNEUROSCI.0047-08.2008

74. Satoh T, Lipton SA (2007) Redox regulation of neuronal survival mediated by electrophilic compounds. Trends Neurosci 30(1):37-45. doi:10.1016/j.tins.2006.11.004

75. Bindoli A, Rigobello MP (2013) Principles in redox signaling: from chemistry to functional significance. Antioxid Redox Signal 18(13):1557-1593. doi:10.1089/ars.2012.4655

76. Salazar H, Llorente I, Jara-Oseguera A, Garcia-Villegas R, Munari M, Gordon SE, Islas LD, Rosenbaum T (2008) A single N-terminal cysteine in TRPV1 determines activation by pungent compounds from onion and garlic. Nat Neurosci 11(3):255-261. doi:10.1038/nn2056

77. Gaudet R (2008) A primer on ankyrin repeat function in TRP channels and beyond. Mol Biosyst 4(5):372-379

78. Hu H, Bandell M, Petrus MJ, Zhu MX, Patapoutian A (2009) Zinc activates damage-sensing TRPA1 ion channels. Nat Chem Biol 5(3):183-190. doi:10.1038/nchembio.146

79. Nagatomo K, Ishii H, Yamamoto T, Nakajo K, Kubo Y (2010) The Met268Pro mutation of mouse TRPA1 changes the effect of caffeine from activation to suppression. Biophys $\mathrm{J}$ 99(11):3609-3618. doi:10.1016/j.bpj.2010.10.014

80. Kozai D, Kabasawa Y, Ebert M, Kiyonaka S, Firman OY, Numata T, Takahashi N, Mori Y, Ohwada T (2014) Transnitrosylation directs TRPA1 selectivity in N-nitrosamine activators. Mol Pharmacol 85(1):175-185. doi:10.1124/mol.113.088864

81. Bessac BF, Sivula M, von Hehn CA, Escalera J, Cohn L, Jordt SE (2008) TRPA1 is a major oxidant sensor in murine airway sensory neurons. J Clin Invest 118(5):1899-1910. doi:10.1172/JCI34192

82. Sadofsky LR, Boa AN, Maher SA, Birrell MA, Belvisi MG, Morice AH (2011) TRPA1 is activated by direct addition of cysteine residues to the N-hydroxysuccinyl esters of acrylic and cinnamic acids. Pharmacol Res: Off J Ital Pharmacol Soc 63(1):30-36. doi:10.1016/j. phrs.2010.11.004 
83. Sawada Y, Hosokawa H, Matsumura K, Kobayashi S (2008) Activation of transient receptor potential ankyrin 1 by hydrogen peroxide. Eur J Neurosci 27(5):1131-1142. doi:10.1111/j.1460-9568.2008.06093.x

84. Taylor-Clark TE, Undem BJ (2010) Ozone activates airway nerves via the selective stimulation of TRPA1 ion channels. J Physiol 588(Pt 3):423-433. doi:10.1113/jphysiol.2009.183301

85. Hill K, Schaefer M (2009) Ultraviolet light and photosensitising agents activate TRPA1 via generation of oxidative stress. Cell Calcium 45(2):155-164. doi:10.1016/j.ceca.2008.08.001

86. Miyamoto T, Dubin AE, Petrus MJ, Patapoutian A (2009) TRPV1 and TRPA1 mediate peripheral nitric oxide-induced nociception in mice. PLoS One 4(10):e7596. doi:10.1371/ journal.pone. 0007596

87. Taylor-Clark TE, McAlexander MA, Nassenstein C, Sheardown SA, Wilson S, Thornton J, Carr MJ, Undem BJ (2008) Relative contributions of TRPA1 and TRPV1 channels in the activation of vagal bronchopulmonary $\mathrm{C}$-fibres by the endogenous autacoid 4-oxononenal. $\mathrm{J}$ Physiol 586(14):3447-3459. doi:10.1113/jphysiol.2008.153585

88. McNamara CR, Mandel-Brehm J, Bautista DM, Siemens J, Deranian KL, Zhao M, Hayward NJ, Chong JA, Julius D, Moran MM, Fanger CM (2007) TRPA1 mediates formalin-induced pain. Proc Natl Acad Sci U S A 104(33):13525-13530. doi:10.1073/pnas.0705924104

89. Petrus M, Peier AM, Bandell M, Hwang SW, Huynh T, Olney N, Jegla T, Patapoutian A (2007) A role of TRPA1 in mechanical hyperalgesia is revealed by pharmacological inhibition. Mol Pain 3:40. doi:10.1186/1744-8069-3-40

90. Strassmaier T, Bakthavatchalam R (2011) Transient receptor potential A1 modulators. Curr Top Med Chem 11(17):2227-2236

91. Andrade EL, Meotti FC, Calixto JB (2012) TRPA1 antagonists as potential analgesic drugs. Pharmacol Ther 133(2):189-204. doi:10.1016/j.pharmthera.2011.10.008

92. Brederson JD, Kym PR, Szallasi A (2013) Targeting TRP channels for pain relief. Eur J Pharmacol 716(1-3):61-76. doi:10.1016/j.ejphar.2013.03.003

93. Klement G, Eisele L, Malinowsky D, Nolting A, Svensson M, Terp G, Weigelt D, Dabrowski M (2013) Characterization of a ligand binding site in the human transient receptor potential ankyrin 1 pore. Biophys J 104(4):798-806. doi:10.1016/j.bpj.2013.01.008

94. Bianchi BR, Zhang XF, Reilly RM, Kym PR, Yao BB, Chen J (2012) Species comparison and pharmacological characterization of human, monkey, rat, and mouse TRPA1 channels. J Pharmacol Exp Ther 341(2):360-368. doi:10.1124/jpet.111.189902

95. Chen J, Kym PR (2009) TRPA1: the species difference. J Gen Physiol 133(6):623-625. doi:10.1085/jgp.200910246

96. Hess DT, Matsumoto A, Kim SO, Marshall HE, Stamler JS (2005) Protein S-nitrosylation: purview and parameters. Nat Rev Mol Cell Biol 6(2):150-166. doi:10.1038/nrm1569

97. Smith BC, Marletta MA (2012) Mechanisms of S-nitrosothiol formation and selectivity in nitric oxide signaling. Curr Opin Chem Biol 16(5-6):498-506. doi:10.1016/j. cbpa.2012.10.016

98. Alderton WK, Cooper CE, Knowles RG (2001) Nitric oxide synthases: structure, function and inhibition. Biochem J 357(Pt 3):593-615

99. Stamler JS, Hess DT (2010) Nascent nitrosylases. Nat Cell Biol 12(11):1024-1026. doi:10.1038/ncb1110-1024

100. Seth D, Stamler JS (2011) The SNO-proteome: causation and classifications. Curr Opin Chem Biol 15(1):129-136. doi:10.1016/j.cbpa.2010.10.012

101. Anand P, Stamler JS (2012) Enzymatic mechanisms regulating protein S-nitrosylation: implications in health and disease. J Mol Med 90(3):233-244. doi:10.1007/s00109-012-0878-z

102. Nakamura T, Lipton SA (2013) Emerging role of protein-protein transnitrosylation in cell signaling pathways. Antioxid Redox Signal 18(3):239-249. doi:10.1089/ars.2012.4703

103. Pawloski JR, Hess DT, Stamler JS (2001) Export by red blood cells of nitric oxide bioactivity. Nature 409(6820):622-626. doi:10.1038/35054560

104. Mitchell DA, Marletta MA (2005) Thioredoxin catalyzes the S-nitrosation of the caspase-3 active site cysteine. Nat Chem Biol 1(3):154-158. doi:10.1038/nchembio720 
105. Kornberg MD, Sen N, Hara MR, Juluri KR, Nguyen JV, Snowman AM, Law L, Hester LD, Snyder SH (2010) GAPDH mediates nitrosylation of nuclear proteins. Nat Cell Biol 12(11):1094-1100. doi:10.1038/ncb2114

106. Nakamura T, Wang L, Wong CC, Scott FL, Eckelman BP, Han X, Tzitzilonis C, Meng F, Gu Z, Holland EA, Clemente AT, Okamoto S, Salvesen GS, Riek R, Yates JR 3rd, Lipton SA (2010) Transnitrosylation of XIAP regulates caspase-dependent neuronal cell death. Mol Cell 39(2):184-195. doi:10.1016/j.molcel.2010.07.002

107. Foster MW, McMahon TJ, Stamler JS (2003) S-nitrosylation in health and disease. Trends Mol Med 9(4):160-168

108. Makita N, Kabasawa Y, Otani Y, Firman SJ, Hashimoto M, Nakaya M, Nishihara H, Nangaku M, Kurose H, Ohwada T, Iiri T (2013) Attenuated desensitization of beta-adrenergic receptor by water-soluble N-nitrosamines that induce S-nitrosylation without NO release. Circ Res 112(2):327-334. doi:10.1161/CIRCRESAHA.112.277665

109. Ohwada T, Miura M, Tanaka H, Sakamoto S, Yamaguchi K, Ikeda H, Inagaki S (2001) Structural features of aliphatic N-nitrosamines of 7-azabicyclo[2.2.1]heptanes that facilitate N-NO bond cleavage. J Am Chem Soc 123(42):10164-10172

110. Yanagimoto T, Toyota T, Matsuki N, Makino Y, Uchiyama S, Ohwada T (2007) Transnitrosation of thiols from aliphatic N-nitrosamines: S-nitrosation and indirect generation of nitric oxide. J Am Chem Soc 129(4):736-737. doi:10.1021/ja0658259

111. Ohwada T, Ishikawa S, Mine Y, Inami K, Yanagimoto T, Karaki F, Kabasawa Y, Otani Y, Mochizuki M (2011) 7-azabicyclo[2.2.1]heptane as a structural motif to block mutagenicity of nitrosamines. Bioorg Med Chem 19(8):2726-2741. doi:10.1016/j.bmc.2011.02.049

112. Vazquez G, Wedel BJ, Aziz O, Trebak M, Putney JW Jr (2004) The mammalian TRPC cation channels. Biochim Biophys Acta 1742(1-3):21-36. doi:10.1016/j.bbamcr.2004.08.015

113. Mio K, Ogura T, Kiyonaka S, Hiroaki Y, Tanimura Y, Fujiyoshi Y, Mori Y, Sato C (2007) The TRPC3 channel has a large internal chamber surrounded by signal sensing antennas. J Mol Biol 367(2):373-383. doi:10.1016/j.jmb.2006.12.043

114. Hofmann T, Schaefer M, Schultz G, Gudermann T (2002) Subunit composition of mammalian transient receptor potential channels in living cells. Proc Natl Acad Sci U S A 99(11):7461-7466. doi:10.1073/pnas.102596199

115. Hofmann T, Obukhov AG, Schaefer M, Harteneck C, Gudermann T, Schultz G (1999) Direct activation of human TRPC6 and TRPC3 channels by diacylglycerol. Nature 397(6716):259263. doi:10.1038/16711

116. Kiselyov K, Xu X, Mozhayeva G, Kuo T, Pessah I, Mignery G, Zhu X, Birnbaumer L, Muallem S (1998) Functional interaction between InsP3 receptors and store-operated Htrp3 channels. Nature 396(6710):478-482. doi:10.1038/24890

117. Kiselyov KI, Shin DM, Wang Y, Pessah IN, Allen PD, Muallem S (2000) Gating of storeoperated channels by conformational coupling to ryanodine receptors. Mol Cell 6(2):421-431

118. Vazquez G, Bird GS, Mori Y, Putney JW Jr (2006) Native TRPC7 channel activation by an inositol trisphosphate receptor-dependent mechanism. J Biol Chem 281(35):25250-25258. doi:10.1074/jbc.M604994200

119. Brazer SC, Singh BB, Liu X, Swaim W, Ambudkar IS (2003) Caveolin-1 contributes to assembly of store-operated $\mathrm{Ca} 2+$ influx channels by regulating plasma membrane localization of TRPC1. J Biol Chem 278(29):27208-27215. doi:10.1074/jbc.M301118200

120. Patterson RL, van Rossum DB, Ford DL, Hurt KJ, Bae SS, Suh PG, Kurosaki T, Snyder SH, Gill DL (2002) Phospholipase C-gamma is required for agonist-induced Ca2+ entry. Cell 111(4):529-541

121. Nishida M, Sugimoto K, Hara Y, Mori E, Morii T, Kurosaki T, Mori Y (2003) Amplification of receptor signalling by $\mathrm{Ca} 2+$ entry-mediated translocation and activation of PLCgamma2 in B lymphocytes. EMBO J 22(18):4677-4688. doi:10.1093/emboj/cdg457

122. Numaga T, Nishida M, Kiyonaka S, Kato K, Katano M, Mori E, Kurosaki T, Inoue R, Hikida M, Putney JW Jr, Mori Y (2010) Ca2+ influx and protein scaffolding via TRPC3 sustain PKCbeta and ERK activation in B cells. J Cell Sci 123(Pt 6):927-938. doi:10.1242/jcs.061051 
123. Mery L, Strauss B, Dufour JF, Krause KH, Hoth M (2002) The PDZ-interacting domain of TRPC4 controls its localization and surface expression in HEK293 cells. J Cell Sci 115(Pt 17):3497-3508

124. Lussier MP, Lepage PK, Bousquet SM, Boulay G (2008) RNF24, a new TRPC interacting protein, causes the intracellular retention of TRPC. Cell Calcium 43(5):432-443. doi:10.1016/j.ceca.2007.07.009

125. Singh BB, Lockwich TP, Bandyopadhyay BC, Liu X, Bollimuntha S, Brazer SC, Combs C, Das S, Leenders AG, Sheng ZH, Knepper MA, Ambudkar SV, Ambudkar IS (2004) VAMP2-dependent exocytosis regulates plasma membrane insertion of TRPC3 channels and contributes to agonist-stimulated Ca2+ influx. Mol Cell 15(4):635-646. doi:10.1016/j. molcel.2004.07.010

126. Wes PD, Chevesich J, Jeromin A, Rosenberg C, Stetten G, Montell C (1995) TRPC1, a human homolog of a Drosophila store-operated channel. Proc Natl Acad Sci U S A 92(21):9652-9656

127. Zitt C, Zobel A, Obukhov AG, Harteneck C, Kalkbrenner F, Luckhoff A, Schultz G (1996) Cloning and functional expression of a human $\mathrm{Ca} 2+-$ permeable cation channel activated by calcium store depletion. Neuron 16(6):1189-1196

128. Zhu X, Jiang M, Peyton M, Boulay G, Hurst R, Stefani E, Birnbaumer L (1996) trp, a novel mammalian gene family essential for agonist-activated capacitative $\mathrm{Ca} 2+$ entry. Cell 85(5):661-671

129. Liu X, Cheng KT, Bandyopadhyay BC, Pani B, Dietrich A, Paria BC, Swaim WD, Beech D, Yildrim E, Singh BB, Birnbaumer L, Ambudkar IS (2007) Attenuation of store-operated $\mathrm{Ca} 2+$ current impairs salivary gland fluid secretion in TRPC1(-I-) mice. Proc Natl Acad Sci U S A 104(44):17542-17547. doi:10.1073/pnas.0701254104

130. Mori Y, Wakamori M, Miyakawa T, Hermosura M, Hara Y, Nishida M, Hirose K, Mizushima A, Kurosaki M, Mori E, Gotoh K, Okada T, Fleig A, Penner R, Iino M, Kurosaki T (2002) Transient receptor potential 1 regulates capacitative $\mathrm{Ca}(2+)$ entry and $\mathrm{Ca}(2+)$ release from endoplasmic reticulum in B lymphocytes. J Exp Med 195(6):673-681

131. Poteser M, Graziani A, Rosker C, Eder P, Derler I, Kahr H, Zhu MX, Romanin C, Groschner K (2006) TRPC3 and TRPC4 associate to form a redox-sensitive cation channel. Evidence for expression of native TRPC3-TRPC4 heteromeric channels in endothelial cells. J Biol Chem 281(19):13588-13595. doi:10.1074/jbc.M512205200

132. Maroto R, Raso A, Wood TG, Kurosky A, Martinac B, Hamill OP (2005) TRPC1 forms the stretch-activated cation channel in vertebrate cells. Nat Cell Biol 7(2):179-185. doi:10.1038/ ncb1218

133. Spassova MA, Hewavitharana T, Xu W, Soboloff J, Gill DL (2006) A common mechanism underlies stretch activation and receptor activation of TRPC6 channels. Proc Natl Acad Sci U S A 103(44):16586-16591. doi:10.1073/pnas.0606894103

134. Seo K, Rainer PP, Lee DI, Hao S, Bedja D, Birnbaumer L, Cingolani OH, Kass DA (2014) Hyperactive adverse mechanical stress responses in dystrophic heart are coupled to transient receptor potential canonical 6 and blocked by cGMP-protein kinase G modulation. Circ Res 114(5):823-832. doi:10.1161/CIRCRESAHA.114.302614

135. Weissmann N, Sydykov A, Kalwa H, Storch U, Fuchs B, Mederos y Schnitzler M, Brandes RP, Grimminger F, Meissner M, Freichel M, Offermanns S, Veit F, Pak O, Krause KH, Schermuly RT, Brewer AC, Schmidt HH, Seeger W, Shah AM, Gudermann T, Ghofrani HA, Dietrich A (2012) Activation of TRPC6 channels is essential for lung ischaemia-reperfusion induced oedema in mice. Nat Commun 3:649. doi:10.1038/ncomms1660

136. Inoue R, Jensen LJ, Jian Z, Shi J, Hai L, Lurie AI, Henriksen FH, Salomonsson M, Morita H, Kawarabayashi Y, Mori M, Mori Y, Ito Y (2009) Synergistic activation of vascular TRPC6 channel by receptor and mechanical stimulation via phospholipase C/diacylglycerol and phospholipase A2/omega-hydroxylase/20-HETE pathways. Circ Res 104(12):1399-1409. doi:10.1161/CIRCRESAHA.108.193227

137. Levy D, Kenchaiah S, Larson MG, Benjamin EJ, Kupka MJ, Ho KK, Murabito JM, Vasan RS (2002) Long-term trends in the incidence of and survival with heart failure. N Engl J Med 347(18):1397-1402. doi:10.1056/NEJMoa020265 
138. Klein L, O'Connor CM, Gattis WA, Zampino M, de Luca L, Vitarelli A, Fedele F, Gheorghiade M (2003) Pharmacologic therapy for patients with chronic heart failure and reduced systolic function: review of trials and practical considerations. Am J Cardiol 91(9A):18F-40F

139. Levy D, Garrison RJ, Savage DD, Kannel WB, Castelli WP (1990) Prognostic implications of echocardiographically determined left ventricular mass in the Framingham Heart Study. N Engl J Med 322(22):1561-1566. doi:10.1056/NEJM199005313222203

140. Frey N, Olson EN (2003) Cardiac hypertrophy: the good, the bad, and the ugly. Annu Rev Physiol 65:45-79. doi:10.1146/annurev.physiol.65.092101.142243

141. Eder P, Molkentin JD (2011) TRPC channels as effectors of cardiac hypertrophy. Circ Res 108(2):265-272. doi:10.1161/CIRCRESAHA.110.225888

142. Bush EW, Hood DB, Papst PJ, Chapo JA, Minobe W, Bristow MR, Olson EN, McKinsey TA (2006) Canonical transient receptor potential channels promote cardiomyocyte hypertrophy through activation of calcineurin signaling. J Biol Chem 281(44):33487-33496. doi:10.1074/ jbc.M605536200

143. Wilkins BJ, Dai YS, Bueno OF, Parsons SA, Xu J, Plank DM, Jones F, Kimball TR, Molkentin JD (2004) Calcineurin/NFAT coupling participates in pathological, but not physiological, cardiac hypertrophy. Circ Res 94(1):110-118. doi:10.1161/01.RES.0000109415.17511.18

144. Heineke J, Molkentin JD (2006) Regulation of cardiac hypertrophy by intracellular signalling pathways. Nat Rev Mol Cell Biol 7(8):589-600. doi:10.1038/nrm1983

145. Roderick HL, Bootman MD (2007) Pacemaking, arrhythmias, inotropy and hypertrophy: the many possible facets of IP3 signalling in cardiac myocytes. J Physiol 581(Pt 3):883-884. doi:10.1113/jphysiol.2007.133819

146. Colella M, Grisan F, Robert V, Turner JD, Thomas AP, Pozzan T (2008) Ca2+ oscillation frequency decoding in cardiac cell hypertrophy: role of calcineurin/NFAT as $\mathrm{Ca} 2+$ signal integrators. Proc Natl Acad Sci U S A 105(8):2859-2864. doi:10.1073/pnas.0712316105

147. Brenner JS, Dolmetsch RE (2007) TrpC3 regulates hypertrophy-associated gene expression without affecting myocyte beating or cell size. PLoS One 2(8):e802. doi:10.1371/journal. pone.0000802

148. Nishida M, Onohara N, Sato Y, Suda R, Ogushi M, Tanabe S, Inoue R, Mori Y, Kurose H (2007) Galpha12/13-mediated up-regulation of TRPC6 negatively regulates endothelin-1induced cardiac myofibroblast formation and collagen synthesis through nuclear factor of activated $\mathrm{T}$ cells activation. J Biol Chem 282(32):23117-23128. doi:10.1074/jbc. M611780200

149. Davis J, Burr AR, Davis GF, Birnbaumer L, Molkentin JD (2012) A TRPC6-dependent pathway for myofibroblast transdifferentiation and wound healing in vivo. Dev Cell 23(4):705-715. doi:10.1016/j.devcel.2012.08.017

150. Nakayama H, Wilkin BJ, Bodi I, Molkentin JD (2006) Calcineurin-dependent cardiomyopathy is activated by TRPC in the adult mouse heart. FASEB J: Off Publ Fed Am Soc Exp Biol 20(10):1660-1670. doi:10.1096/fj.05-5560com

151. Seo K, Rainer PP, Shalkey Hahn V, Lee DI, Jo SH, Andersen A, Liu T, Xu X, Willette RN, Lepore JJ, Marino JP Jr, Birnbaumer L, Schnackenberg CG, Kass DA (2014) Combined TRPC3 and TRPC6 blockade by selective small-molecule or genetic deletion inhibits pathological cardiac hypertrophy. Proc Natl Acad Sci U S A 111(4):1551-1556. doi:10.1073/ pnas.1308963111

152. Dietrich A, Mederos YSM, Gollasch M, Gross V, Storch U, Dubrovska G, Obst M, Yildirim E, Salanova B, Kalwa H, Essin K, Pinkenburg O, Luft FC, Gudermann T, Birnbaumer L (2005) Increased vascular smooth muscle contractility in TRPC6-/- mice. Mol Cell Biol 25(16):6980-6989. doi:10.1128/MCB.25.16.6980-6989.2005

153. Ohba T, Watanabe H, Murakami M, Takahashi Y, Iino K, Kuromitsu S, Mori Y, Ono K, Iijima T, Ito H (2007) Upregulation of TRPC1 in the development of cardiac hypertrophy. J Mol Cell Cardiol 42(3):498-507

154. Seth M, Zhang ZS, Mao L, Graham V, Burch J, Stiber J, Tsiokas L, Winn M, Abramowitz J, Rockman HA, Birnbaumer L, Rosenberg P (2009) TRPC1 channels are critical for hypertrophic signaling in the heart. Circ Res 105(10):1023-1030. doi:10.1161/CIRCRESAHA.109.206581 
155. Takahashi S, Lin H, Geshi N, Mori Y, Kawarabayashi Y, Takami N, Mori MX, Honda A, Inoue R (2008) Nitric oxide-cGMP-protein kinase G pathway negatively regulates vascular transient receptor potential channel TRPC6. J Physiol 586(Pt 17):4209-4223. doi:10.1113/ jphysiol.2008.156083

156. Nishioka K, Nishida M, Ariyoshi M, Jian Z, Saiki S, Hirano M, Nakaya M, Sato Y, Kita S, Iwamoto T, Hirano K, Inoue R, Kurose H (2011) Cilostazol suppresses angiotensin II-induced vasoconstriction via protein kinase A-mediated phosphorylation of the transient receptor potential canonical 6 channel. Arterioscler Thromb Vasc Biol 31(10):2278-2286. doi:10.1161/ ATVBAHA.110.221010

157. Koitabashi N, Aiba T, Hesketh GG, Rowell J, Zhang M, Takimoto E, Tomaselli GF, Kass DA (2010) Cyclic GMP/PKG-dependent inhibition of TRPC6 channel activity and expression negatively regulates cardiomyocyte NFAT activation Novel mechanism of cardiac stress modulation by PDE5 inhibition. J Mol Cell Cardiol 48(4):713-724. doi:10.1016/j. yjmcc.2009.11.015

158. Kinoshita H, Kuwahara K, Nishida M, Jian Z, Rong X, Kiyonaka S, Kuwabara Y, Kurose H, Inoue R, Mori Y, Li Y, Nakagawa Y, Usami S, Fujiwara M, Yamada Y, Minami T, Ueshima K, Nakao K (2010) Inhibition of TRPC6 channel activity contributes to the antihypertrophic effects of natriuretic peptides-guanylyl cyclase-A signaling in the heart. Circ Res 106(12):1849-1860. doi:10.1161/CIRCRESAHA.109.208314

159. Nishida M, Watanabe K, Sato Y, Nakaya M, Kitajima N, Ide T, Inoue R, Kurose H (2010) Phosphorylation of TRPC6 channels at Thr69 is required for anti-hypertrophic effects of phosphodiesterase 5 inhibition. J Biol Chem 285(17):13244-13253. doi:10.1074/jbc. M109.074104

160. Kitajima N, Watanabe K, Morimoto S, Sato Y, Kiyonaka S, Hoshijima M, Ikeda Y, Nakaya M, Ide T, Mori Y, Kurose H, Nishida M. (2011) TRPC3-mediated Ca2+ influx contributes to Rac1-mediated production of reactive oxygen species in MLP-deficient mouse hearts. Biochem Biophys Res Commun 409(1):108-113

161. Steinberg X, Lespay-Rebolledo C, Brauchi S (2014) A structural view of ligand-dependent activation in thermoTRP channels. Front Physiol 5:171. doi:10.3389/fphys.2014.00171

162. Doerner JF, Gisselmann G, Hatt H, Wetzel CH (2007) Transient receptor potential channel A1 is directly gated by calcium ions. J Biol Chem 282(18):13180-13189. doi:10.1074/jbc. M607849200

163. Fujita F, Uchida K, Moriyama T, Shima A, Shibasaki K, Inada H, Sokabe T, Tominaga M (2008) Intracellular alkalization causes pain sensation through activation of TRPA1 in mice. J Clin Invest 118(12):4049-4057

164. Zhang XF, Chen J, Faltynek CR, Moreland RB, Neelands TR (2008) Transient receptor potential A1 mediates an osmotically activated ion channel. Eur J Neurosci 27(3):605-611. doi:10.1111/j.1460-9568.2008.06030.x

165. Caspani O, Heppenstall PA (2009) TRPA1 and cold transduction: an unresolved issue? J Gen Physiol 133(3):245-249. doi:10.1085/jgp.200810136

166. Nilius B, Prenen J, Owsianik G (2011) Irritating channels: the case of TRPA1. J Physiol 589(Pt 7):1543-1549. doi:10.1113/jphysiol.2010.200717

167. Nilius B, Appendino G, Owsianik G (2012) The transient receptor potential channel TRPA1: from gene to pathophysiology. Pflugers Arch: Eur J Physiol 464(5):425-458. doi:10.1007/ s00424-012-1158-z

168. Bautista DM, Pellegrino M, Tsunozaki M (2013) TRPA1: a gatekeeper for inflammation. Annu Rev Physiol 75:181-200

169. Schleifer H, Doleschal B, Lichtenegger M, Oppenrieder R, Derler I, Frischauf I, Glasnov TN, Kappe CO, Romanin C, Groschner K (2012) Novel pyrazole compounds for pharmacological discrimination between receptor-operated and store-operated $\mathrm{Ca}(2+)$ entry pathways. $\mathrm{Br} \mathrm{J}$ Pharmacol 167(8):1712-1722 